\title{
ПЛ-5
}

\section{ПРОБЛЕМЫ ЭКОАНАЛИТИЧЕСКОГО КОНТРОЛЯ ПРИРОДНЫХ ВОД}

Папина Т.C.

Институт водных и экологических проблем Сибирского отделения РАН, Барнаул, Россия

tanya.papina@mail.ru

DOI: 10.26902/ASFE-11_06

В докладе рассматриваются методические вопросы организации экологоаналитического контроля водных объектов, включая исследования по обоснованию отбора представительной (репрезентативной) пробы в стратифицированном речном потоке, а также дается анализ и систематизация основных ошибок, возникающих при проведении эколого-аналитического контроля водных объектов в отечественной практике работ.

Особое внимание в докладе будет уделено основным источникам систематических погрешностей, возникающих при проведении мониторинга водных объектов. Дается анализ современных российских и международных нормативных документов по отбору и анализу проб природных вод и атмосферных осадков, рассматривается влияние различных стадий эко-аналитического контроля на достоверность получаемых конечных результатов, приводится обзор существующих методов оценки качества аналитических (лабораторных) данных. Подробно рассмотрены существующие современные критерии (нормативы) оценки качества воды с учетом целей водопользования, а также условий естественного функционирования различного типа водных экосистем, дано сравнение отечественных и зарубежных стандартов качества питьевых и природных вод.

Утверждается, что при оценке уровня загрязнения природной среды, основанной исключительно на результатах химического анализа проб (например, построение модели распространения загрязняющих веществ от источника их эмиссии и др.), химик-аналитик должен быть вовлечен в методическую работу по разработке схем проведения всех стадий эко-аналитического контроля изучаемых природных объектов. 